\title{
Transgene IL-21-Engineered T Cell-Based Vaccine Potently Converts CTL Exhaustion via the Activation of the mTORC1 Pathway in Chronic Infection
}

\author{
Aizhang $\mathrm{Xu}^{1,2^{*}}$, Xueying Zhang1,2*, Rajni Chibbar ${ }^{3}$, Andrew Freywald ${ }^{3}$, \\ Suresh Tikoo ${ }^{4}$, Changyu Zheng ${ }^{5}$, Jim Xiang ${ }^{1,2 \#}$ \\ ${ }^{1}$ Cancer Research, Saskatchewan Cancer Agency, Saskatoon, Canada \\ ${ }^{2}$ Department of Oncology, College of Medicine, University of Saskatchewan, Saskatoon, Canada \\ ${ }^{3}$ Department of Pathology, College of Medicine, University of Saskatchewan, Saskatoon, Canada \\ ${ }^{4}$ School of Public Health, University of Saskatchewan, Saskatoon, Canada \\ ${ }^{5}$ Molecular Physiology and Therapeutic Branch, National Institute of Dental and Craniofacial Research, National Institute of \\ Health, Bethesda, USA \\ Email: "jim.xiang@usask.ca
}

How to cite this paper: $\mathrm{Xu}$, A.Z., Zhang, X.Y., Chibbar, R., Freywald, A., Tikoo, S., Zheng, C.Y. and Xiang, J. (2019) Transgene IL-21-Engineered T Cell-Based Vaccine Potently Converts CTL Exhaustion via the Activation of the mTORC1 Pathway in Chronic Infection. World Journal of Vaccines, 9, 1-21.

https://doi.org/10.4236/wjv.2019.91001

Received: November 6, 2018

Accepted: December 22, 2018

Published: December 25, 2018

Copyright $\odot 2019$ by authors and Scientific Research Publishing Inc. This work is licensed under the Creative Commons Attribution International License (CC BY 4.0).

http://creativecommons.org/licenses/by/4.0/

\section{(c) (i) Open Access}

\begin{abstract}
$\mathrm{CD} 8^{+}$cytotoxic $\mathrm{T}$ lymphocyte (CTL) exhaustion is one of the major obstacles for the effectiveness of virus control in chronic infectious diseases. We previously generated novel ovalbumin (OVA)-specific 41BBL-expressing OVA- $\mathrm{T}_{\mathrm{EXO}}$ and human immunodeficiency virus (HIV-1) Gag-specific Gag- $\mathrm{T}_{\mathrm{EXO}}$ vaccines, inducing therapeutic immunity in wild-type C57BL/6 (B6) mice, and converting CTL exhaustion in recombinant OVA-specific adenovirus $\mathrm{AdV}_{\mathrm{OVA}}$-infected $\mathrm{B} 6\left(\mathrm{AdV}_{\mathrm{OVA}}-\mathrm{B} 6\right)$ mice with chronic infection. IL-21 cytokine plays an important role in controlling chronic infections. Therefore, in this study, we constructed recombinant transgene IL-21-expressing $\mathrm{AdV}_{\mathrm{IL}-21}$, and generated IL-21-expressing OVA- $\mathrm{T}_{\mathrm{EXO} / \mathrm{IL}-21}$ and Gag- $\mathrm{T}_{\mathrm{EXO} / \mathrm{IL} 21}$ vaccines, or control vaccines (OVA- $\mathrm{T}_{\text {EXO/Null }}$ and Gag- $\mathrm{T}_{\text {EXO/Null }}$ ) by infecting OVA- $\mathrm{T}_{\text {EXO }}$ and Gag- $\mathrm{T}_{\text {EXO }}$ cells with $A d V_{\text {IL-21 }}$ or the control $A d V_{\text {Null }}$, lacking transgene, and assessed their effects in $\mathrm{B} 6$ or $\mathrm{AdV}_{\mathrm{OVA}}-\mathrm{B} 6$ mice. We demonstrate that both OVA- $\mathrm{T}_{\text {EXO/L-21 }}$ and control OVA- $\mathrm{T}_{\text {EXO/Null }}$ vaccines are capable of converting CTL exhaustion in chronic infection. However, the OVA- $\mathrm{T}_{\text {EXo/IL-21 }}$ vaccine more efficiently rescues exhausted CTLs by increasing stronger CTL proliferation and effector cytokine IFN- $\gamma$ expression than the control OVA- $\mathrm{T}_{\mathrm{EXO} / \mathrm{Null}}$ vaccine in $\mathrm{AdV}_{\mathrm{OVA}}-\mathrm{B} 6$ mice with chronic infection, though both vaccines stimulated comparable OVA-specific CTL responses and protective immunity
\end{abstract}


against OVA-expressing BL6-10 $0_{\mathrm{OVA}}$ melanoma lung metastasis in wild-type B6 mice. In vivo, the OVA-T $\mathrm{EXO} / \mathrm{L}-21$-stimulated CTLs more efficiently up-regulate phosphorylation of mTORC1-controlled EIF4E and expression of mTORC1regulated $\mathrm{T}$-bet molecule than the control OVA-T $\mathrm{TXX}_{\mathrm{E} \text { Null }}$-stimulated ones. Importantly, the Gag- $\mathrm{T}_{\mathrm{EXO} / \mathrm{IL} 21}$ vaccine induces stronger Gag-specific therapeutic immunity against established Gag-expressing BL6-10 $0_{\text {Gag }}$ melanoma lung metastases than the control Gag- $\mathrm{T}_{\text {EXo/Null }}$ vaccine in chronic infection. Therefore, this study should have a strong impact on developing new therapeutic vaccines for patients with chronic infections.

\section{Keywords}

IL-21, Chronic Infection, CTL Exhaustion, Exosome, T Cell Vaccine

\section{Introduction}

During acute viral infections, both innate and adaptive immunity work together contribute to the clearance of the pathogens [1]. Many acute infections stimulate massive $\mathrm{CD}^{+}$cytotoxic $\mathrm{T}$ lymphocyte (CTL) responses that play an important role in controlling invading viruses and these responses are divided into three phases: expansion, contraction and memory [1]. In the expansion phase, the infectious pathogen triggers proliferation of effector CTLs cytolytic to virus-infected cells. This is followed by the contraction phase, where $90 \%-95 \%$ of effector CTLs die of apoptosis induced by cytolytic granzyme-B (GB)-mediated lethal hit, which is produced by regulatory $\mathrm{T}$ (Treg) cells [2]. Typically, only $5 \%-10 \%$ of the expanded ensemble of CTLs survive and proceed in the final stage to constitute the long-term memory CTLs capable of turning on rapid responses, when re-encounting the same pathogen [1].

Although CTLs are effective in controlling acute viral infections, they often become functionally deficient or exhausted in chronic infections due to persistent pathogen presence [3]. The common characteristic of chronic infections, such as human immunodeficiency virus [4], hepatitis C virus (HCV) or hepatitis $B$ virus (HBV) is that anti-virus CTLs are initially stimulated, but later become quantitatively and qualitatively defective leading to a stepwise progression of functional exhaustion and incapability of clearing pathogens [3]. Phenotypically, these exhausted CTLs express some immune inhibitory molecules, such as programmed death-1 (PD-1), T-cell Ig and mucin protein-3 (TIM-3), and lymphocyte-activation gene 3 (LAG-3) [3] [5] [6]. This makes CTLs ineffective in the stimulation-induced i) production of cytokines, including IL-2 and IFN- $\gamma$ [7], ii) cell proliferation, and iii) cytolytic effect on virus-infected cells [8] [9] [10] [11]. Severe CTL exhaustion often strongly correlates with high viral loads [12]. It has been found that longer duration of the chronic infection or severe loss of $\mathrm{CD} 4^{+} \mathrm{T}$ cell help often leads to more serious CTL exhaustion [1] [13], and the final stage of CTL exhaustion often results in depletion of virus-specific CTLs [8] [10]. 
Consistent with this, the CTL exhaustion is one of the major reasons for ineffective HIV control in infected patients.

Mice with lymphocytic choriomeningitis virus (LCMV) infection are frequently used for investigating LCMV-specific CTL responses, since the nature of the virus makes it an excellent mouse infection model. For example, different LCMV strains can cause distinct viral infections both acute and chronic. The Armstrong strain induces an acute viral infection, whereas LCMV clone 13 infection results in viremia that can last up to 3 months with virus persisting in the brain and kidneys [10], leading to a chronic viral infection [14]. Interestingly, these two strains only differ from each other in 2 amino acids, but preserve all epitopes for T-cell receptors, thus allowing us to easily compare CTL responses between dominant and subdominant LCMV viral epitopes [15] [16]. In addition, the latter strain has been extensively applied to study the dynamics of CTL responses and CTL exhaustion, as well as to assess immune therapeutics for the conversion of CTL exhaustion in chronic infections [14] [17]. We have recently established an adenovirus-induced chronic infection model by i.v. infection of $\mathrm{C} 57 \mathrm{BL} / 6$ mice with a recombinant adenovirus $\left(\mathrm{AdV}_{\mathrm{OVA}}\right)$ expressing ovalbumin (OVA). Similar to the situation in the LCMV clone 13-induced chronic infection, our mice with the $\mathrm{AdV}_{\mathrm{OVA}^{-}}$-induced chronic infection demonstrated OVA-specific CD $44^{+} \mathrm{PD}-1^{+} \mathrm{LAG}-3^{+}$memory CTL (mCTL) inflation. These mCTLs were also functionally defective and exhausted [18]. We also found that the PD-1 blockade efficiently converts CTL exhaustion in the OVA-specific chronic infection model [19].

IL-21 cytokine was originally found to be produced by $\mathrm{CD}^{+} \mathrm{T}$ cells [20] and to serve as a "third" signal, functioning in concert with T cell receptor (TCR) activation and $\mathrm{T}$ cell co-stimulation to trigger $\mathrm{CD} 8^{+} \mathrm{T}$ cell responses [21]. Recently, it has been shown that IL-21 plays a significant role in controlling chronic LCMV infection [22] [23] [24]. IL-21 enhances cytolytic and virus control abilities of HIV-specific CTLs in vitro [25] [26], and enhances the viral control in immunodeficiency virus [4]-infected rhesus macaques and HCV- and HIV-1-infected patients [7] [27] [28].

We previously developed a novel ovalbumin (OVA)-specific exosome (EXO)-targeted $\mathrm{T}$ cell-based (OVA- $\mathrm{T}_{\mathrm{EXO}}$ ) vaccine by using non-specific polyclonal $\mathrm{T}$ cells with the uptake of OVA-specific dendritic cell (DC)-released EXO via the CD54/LFA-1 interaction [29]. We demonstrated that the OVA-Texo vaccine was able to directly stimulate potent OVA-specific CTL responses in the absence of $\mathrm{CD}^{+} \mathrm{T}$ cell help by counteracting $\mathrm{CD}^{+} 25^{+} \mathrm{FoxP}^{+}$regulatory $\mathrm{T}$ (Treg) cell suppression [29] [30]. We also developed an HIV-1 Gag-specific T cell-based vaccine, Gag- $\mathrm{T}_{\mathrm{EXO}}$, by using non-specific polyclonal $\mathrm{T}$ cells with the uptake of Gag-specific DC-released EXO and demonstrated that the Gag- $\mathrm{T}_{\text {EXO }}$ vaccine triggered potent Gag-specific immunity against Gag-expressing tumors in transgenic HLA-A2 mice [31]. To enhance its immunogenicity, we generated 4-1BBL-expressing OVA- $\mathrm{T}_{\mathrm{EXO}}$ and Gag- $\mathrm{T}_{\mathrm{EXO}}$ vaccines, and demonstrated that 
the former one triggered potent therapeutic immunity [32]. It also induced an efficient conversion of CTL exhaustion via its CD40L-dependent signaling activation of the mTORC1 pathway in chronic infection models [18].

In this study, we constructed a recombinant adenovirus $\left(\mathrm{AdV}_{\mathrm{IL}-21}\right)$ expressing mouse IL-21 and generated new OVA- $\mathrm{T}_{\mathrm{EXO} / \mathrm{IL}-21}$ and Gag- $\mathrm{T}_{\mathrm{EXO} / \mathrm{IL}-21}$ vaccines engineered to express IL-21 by infection of the above OVA- $\mathrm{T}_{\mathrm{EXO}}$ and Gag- $\mathrm{T}_{\mathrm{EXO}}$ cells with $A_{d V_{\mathrm{IL}-21}}$ as previously described [32]. We assessed the effectiveness of the OVA- $\mathrm{T}_{\mathrm{EXO} / \mathrm{IL}-21}$ vaccine in the conversion of CTL exhaustion and examined the effectiveness of the Gag- $\mathrm{T}_{\text {Exo/L-21 }}$ vaccine in therapeutic immunity against Gag-expressing tumors in chronic infection model. We found that the OVA- $\mathrm{T}_{\text {EXO/IL-21 }}$ vaccination stronger rescued CTL exhaustion than the OVA- $\mathrm{T}_{\text {EXO }}$ vaccine in chronic infection, while Gag- $\mathrm{T}_{\mathrm{ExO} / \mathrm{IL}-21}$ vaccination triggered more potent therapeutic immunity against established Gag-expressing BL6-10 $0_{\text {Gag }}$ tumor lung metastases, when compared to the Gag- $\mathrm{T}_{\text {EXO }}$ vaccine in chronic infection.

\section{Materials and Methods}

\subsection{Reagents, Cell Lines and Animals}

Chicken ovalbumin (OVA) was obtained from SIGMA-Aldrich Canada Ltd, Oakville, Ontario, Canada. Phycoerythrin (PE)-labeled anti-IFN- $\gamma$ antibody (Ab) was obtained from BD Biosciences (Mississauga, ON, Canada). Biotin-labeled anti-T-bet, anti-phosphor-EIF4E (S209), anti-CD44, anti-PD-1, anti-PD-L1 and anti-LAG3 Abs were obtained from eBioscience (San Diego, CA). PE-labeled $\mathrm{H}-2 \mathrm{~K}^{\mathrm{b}} / \mathrm{OVA}_{257-264}$ tetramer (PE-tetramer) and Fluorescein isothiocyanate (FITC)-labeled anti-CD8 Ab were obtained from Beckman Coulter (Miami, FL). Rabbit anti-CD9 and anti-LAMP-1 Abs were obtained from BD Bioscience. The H-2 $\mathrm{K}^{\mathrm{b}}$-restricted OVAI $\left(\mathrm{OVA}_{257-264}\right.$, SIINFEKL) peptide and the control Lewis lung carcinoma $\mathrm{H}-2 \mathrm{~K}^{\mathrm{b}}$-restricted MutI (FEQNTAQP) peptide were obtained from Multiple Peptide Systems (San Diego, CA). All cytokines were obtained from Peprotech (Peprotech, Rocky Hill, NJ). Recombinant adenoviral vectors, including transgene OVA-expressing $\mathrm{AdV}_{\mathrm{OVA}}$, transgene Gag-expressing $A_{d V_{\text {Gag }}}$ and the no transgene-expressing $A_{d V} V_{\text {Null }}$ were available in our laboratory [18] [32]. Adenoviral vector $\mathrm{AdV}_{\mathrm{IL}-21}$ expressing mouse IL-21 was constructed by the insertion of IL-21 open reading frame of pUNO1-mIL-21 vector (InVivoGen, San Diego, CA) into the pShuttle-CMV vector (Stratagene, La Jolla, CA) by recombinant technology as we previously described [18] [32]. The Pmel-digested pShuttle-CMV-mIL-21 was transformed into BJ5183 Escherichia coli cells containing pAdEasy-1 backbone vector for the homologous recombination [18] [32]. The recombinant AdV vector was linealized by PacI digestion and transfected into HEK-293 cells using Lipofectamine 2000 (Invitrogene, Carlsbad, CA) to generate AdVIL-21 expressing transgene IL-21 [18] [32]. $\mathrm{AdV}_{\mathrm{IL}-21}$ was then amplified in HEK-293 cells and purified by a series of cesium chloride ultracentrifugation [18] [32]. The highly lung metastatic, OVA- and Gag-expressing BL6-10 OVA and BL6-10Gag mouse B16 melanoma cell lines were 
available in our laboratory [31] [32] [33]. IL-21 enzyme-linked immunosorbent assay (ELISA) kit was obtained from R \& D Systems Inc, Minneapolis, MN. Female 6- to 8-week-old C57BL/6 (B6) (18 - $20 \mathrm{~g}$ ) and OVA-specific T cell receptor (TCR) transgenic OTI mice were obtained from the Jackson Laboratory (Bar Harbor, MA). All experiments were performed according to protocols and guidelines approved by the Animal Research Ethics Board, University of Saskatchewan (Protocol No. 20130020).

\subsection{Preparation of Dendritic Cells and Dendritic Cell-Released Exosomes}

Bone marrow-derived dendritic cells (DCs) were obtained by culturing bone marrow cells of wild-type (WT) B6 mice in culture medium containing granulocyte monocyte colony-stimulating factor (GM-CSF) $(20 \mathrm{ng} / \mathrm{ml})$ and IL-4 (20 $\mathrm{ng} / \mathrm{ml}$ ) for six days, as previously described [29]. DCs were pulsed with OVA $(0.5 \mathrm{mg} / \mathrm{ml})$ for overnight and termed $\mathrm{DC}_{\mathrm{OVA}}$. $\mathrm{DC}_{\mathrm{OVA}}$ stained with various $\mathrm{Abs}$ were analysed by flow cytometry. $\mathrm{DC}_{\mathrm{OVA}}$-released exosomes $\left(\mathrm{EXO}_{\mathrm{OVA}}\right)$ were then purified from $\mathrm{DC}_{\mathrm{OVA}}$ culture supernatants by differential ultracentrifugation [29]. In addition, DCs were also infected with $\operatorname{AdV}_{\text {Gag }}(100 \mathrm{pfu} / \mathrm{cell})$ for overnight in a humidified $37^{\circ} \mathrm{C}, 5 \% \mathrm{CO}_{2}$ incubator, and termed $\mathrm{DC}_{\text {Gag. }} \mathrm{DC}_{\mathrm{Gag}}$-released EXOs were purified from $\mathrm{DC}_{\mathrm{Gag}}$ culture supernatants by ultracentrifugation and termed $\mathrm{EXO}_{\text {Gag. }}$.

\subsection{Preparation of ConA-Stimulated Polyclonal T Cells}

Polyclonal naïve $\mathrm{CD}^{+} \mathrm{T}$ cells were isolated from WT B6 mouse spleens, enriched by passage through nylon wool columns, and then purified by negative selection using anti-mouse CD4 paramagnetic beads (Life Technologies, Waltham, MA), as previously described [34] [35]. Purified polyclonal $\mathrm{CD}^{+} \mathrm{T}$ cells were cultured for 3 days in RPMI 1640 medium, containing IL-2 $(20 \mathrm{U} / \mathrm{ml})$ and ConA $(1 \mu \mathrm{g} / \mathrm{ml})$. CD8 ${ }^{+} \mathrm{T}$ cells were then purified from ConA-activated $\mathrm{T}$ cells using MACS anti-CD8 microbeads (Miltenyi Biotech, Auburn, CA) to yield $\mathrm{CD}^{+} \mathrm{T}$ cell populations with $>95 \%$ purity [29], and termed ConA-T cells.

\subsection{Preparation of the OVA- $\mathrm{T}_{\mathrm{EXO} / \mathrm{L}-21}$ and Gag- $\mathrm{T}_{\mathrm{EXO} / \mathrm{IL}-21}$ Vaccines and the Control OVA-T $\mathrm{T}_{\text {Exo/Null }}$ and Gag- $\mathrm{T}_{\mathrm{EXo} / \mathrm{Null}}$ Vaccines}

The OVA- $\mathrm{T}_{\mathrm{EXO}}$ and Gag- $\mathrm{T}_{\mathrm{EXO}}$ vaccines were generated by the incubation of $\mathrm{CD}^{+} \mathrm{ConA}-\mathrm{T}$ cells with $\mathrm{EXO}_{\mathrm{OVA}}$ or $\mathrm{EXO}_{\mathrm{Gag}}$ at $3 \times 10^{6}$ cells $/ 10 \mu \mathrm{g}$ for 1 hour at $37^{\circ} \mathrm{C}$, followed by the transfection of $\mathrm{T}$ cells with the uptake of $\mathrm{EXO}_{\mathrm{OVA}}$ or EX$\mathrm{O}_{\text {Gag }}$ with $\mathrm{AdV}_{41 B B L}$ at $100 \mathrm{pfu} / \mathrm{cell}$ for another 2 hours to form the vaccines, as previously described [32]. To prepare the OVA- $\mathrm{T}_{\mathrm{EXO} / \mathrm{IL}-21}$ or Gag- $\mathrm{T}_{\mathrm{EXO} / \mathrm{IL}-21}$ and the control OVA- $\mathrm{T}_{\text {EXO/Null }}$ or Gag- $\mathrm{T}_{\text {EXO/Null }}$ vaccines, the above OVA- $\mathrm{T}_{\mathrm{EXO}}$ or Gag- $\mathrm{T}_{\mathrm{EXO}}$ cells were further transfected with $\mathrm{AdV}_{\text {IL-21 }}$ or $\mathrm{AdV}_{\text {Null }}[100 \mathrm{pfu} / \mathrm{cell}]$ for 2 hours to form OVA- $\mathrm{T}_{\mathrm{EXO} / \mathrm{LL}-21}$ or Gag- $\mathrm{T}_{\mathrm{EXO} / \mathrm{IL}-21}$ and the control OVA- $\mathrm{T}_{\mathrm{EXO} / \mathrm{Null}}$ or Gag- $\mathrm{T}_{\mathrm{EXO} / \mathrm{Null}}$ vaccine respectively, as we previously described [32]. 


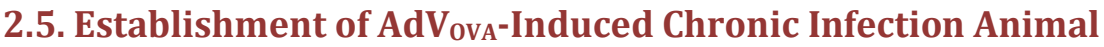 Model}

To develop a chronic infection model, B6 mice (4/group) were intravenously (i.v.) injected with anti-CD4 $\mathrm{Ab}\left(300 \mu \mathrm{g} /\right.$ mouse) to deplete $\mathrm{CD}^{+} \mathrm{T}$ cells, followed by i.v. infection of mice with $\operatorname{AdV}_{\mathrm{OVA}}\left(1 \times 10^{6} \mathrm{pfu} / \mathrm{mouse}\right)$ one day after the anti-CD4 $\mathrm{Ab}$ treatment performed for $\mathrm{CD} 4^{+} \mathrm{T}$ cell depletion. This experimental procedure was aimed to develop a more stringent mouse model of chronic infection, since $\mathrm{AdV}_{\mathrm{OVA}}$ infection of mice was performed under the condition of $\mathrm{CD}^{+} \mathrm{T}$ cell depletion such that the 'helpless' $\mathrm{CD}^{+} \mathrm{T}$ cells activated by $A d V_{\text {OVA }}$ infection became functionally exhausted with severe defects in IFN- $\gamma$ production and cytotoxicity [36]. These mice were chronically $A_{d V_{O V A}}$-infected B6 ( $\left.\mathrm{AdV}_{\mathrm{OVA}}-\mathrm{B} 6\right)$ mice and termed $\mathrm{AdV}_{\mathrm{OVA}}-\mathrm{B} 6$ mice with chronic infection. To develop an acute infection model, B6 mice (4/group) were i.v. infected with recombinant OVA-expressing rLmOVA bacteria [2000 colony forming unit (cfu)/mouse]. These mice were termed rLmOVA-B6 mice. After infections, OVA-specific $\mathrm{CD}^{+} \mathrm{CTL}$ responses in $\mathrm{AdV}_{\mathrm{OVA}^{-}} \mathrm{B} 6$ and rLmOVA-B6 mice were kinetically analyzed by flow cytometry.

\subsection{Flow Cytometric Analysis}

Peripheral blood samples derived from $\mathrm{AdV}_{\mathrm{OVA}}-\mathrm{B} 6$ and rLmOVA-B6 mice were double stained with FITC-CD8 Ab and PE-tetramer and analyzed by flow cytometry to assess $\mathrm{CD}^{+} \mathrm{T}$ cell responses at different days after infection. To increase the amount of OVA-specific $\mathrm{CD}^{+}$memory $\mathrm{T}(\mathrm{Tm})$ cells formed 30 days or over 30 days post infection, such that phenotypes of OVA-specific $\mathrm{CD}^{+} \mathrm{Tm}$ cells can be more accurately analyzed, B6 mice were infected with an increased amount of $\operatorname{AdV}_{\text {OVA }}\left(1.2-1.4 \times 10^{6} \mathrm{pfu} /\right.$ mouse) for the development of chronic infection $\mathrm{AdV}_{\mathrm{OVA}}-\mathrm{B} 6$ mice, while $\mathrm{B} 6$ mice with prior i.v. injection of naïve $\mathrm{CD} 8^{+}$ $\mathrm{T}$ cells $\left(1 \times 10^{3} /\right.$ mouse $)$ purified from OTI mouse spelnocytes were infected with rLmOVA bacteria for the development of acute infection rLmOVA-B6 mice [18]. To assess the phenotype of OVA-specific $\mathrm{CD}^{+} \mathrm{Tm}$ cells, peripheral blood samples derived from $\mathrm{AdV}_{\mathrm{OVA}}-\mathrm{B} 6$ and rLmOVA-B6 mice 60 days post the primary infection were triply stained with FITC-CD8 Ab, PE-tetramer and $\mathrm{PE}-\mathrm{Cy} 5-\mathrm{Abs}$ for various immune molecules, and then analyzed by flow cytometry. To assess the conversion of CTL exhaustion, $\mathrm{AdV}_{\mathrm{OVA}} \mathrm{B} 6$ mice with chronic infection were i.v. immunized with OVA- $\mathrm{T}_{\text {EXO/L-21 }}$ or the control OVA- $\mathrm{T}_{\text {EXO/Null }}$ vaccine $\left(1 \times 10^{6}\right.$ cells/mouse $)$, followed by the analysis of OVA-specific $\mathrm{CD}^{+} \mathrm{T}$ cell proliferation and phenotypes 4 days post immunization. To stain the intracellular molecules, mouse splenocytes derived from $\mathrm{AdV}_{\mathrm{OVA}}-\mathrm{B} 6$ and rLmOVA-B6 mice were first incubated with FcR blocking anti-16/32 Ab (eBioscience) for $30 \mathrm{~min}$ on ice for eliminating any nonspecific staining. The cells were then stained with FITC-CD8 Ab and PE-tetramer, followed by the fixation and permeabilization with Cytofix/Cytoperm (BD Biosciences) according to the manufacturer's instruction. The cells were further stained with PE-Cy5-antibodies 
specific for various molecules such as EIF4E and T-bet, and the expression of these molecules was assessed by flow cytometry. For intracellular staining of IFN- $\gamma$, mouse splenocytes were first incubated in culture medium containing OVAI peptide $(2 \mu \mathrm{g} / \mathrm{ml})$ and Golgi-stop $(0.7 \mu \mathrm{g} / \mathrm{ml})$ (BD Biosciences) at $37^{\circ} \mathrm{C}$ for $5 \mathrm{hrs}$, followed by the incubation with FcR blocking anti-16/32 Ab for 30 min on ice. The cells were then stained with FITC-CD8 Ab and PE-tetramer, followed by fixation and permeabilization with Cytofix/Cytoperm (BD Biosciences). Intracellular staining of IFN- $\gamma$ was conducted using PE-Cy5-anti-IFN- $\gamma \mathrm{Ab}$, and the expression of IFN- $\gamma$ was assessed by flow cytometry. Data were acquired by CytoFlex (Beckman Coulter) and analyzed with FlowJo software (TreeStar, San Diego, CA).

\subsection{Western Blot Analysis}

EXO $(10 \mu \mathrm{g} /$ well $)$ were resolved by sodium dodecyl sulfate-polyacrylamide gel electrophoresis (SDS-PAGE), and subsequently transferred onto the nitrocellulose membrane (Bio-Rad Laboratories, Hercules, CA). The membrane was blocked with 5\% bovine serum albumin (BSA) in PBS, immunoblotted with rabbit anti-CD9 or anti-LAMP-1 Ab, followed by the incubation with anti-rabbit IRDyeR800CW Ab, and then, scanning with the ODYSSEY imager according to manufacturer's instruction (Li-COR Bioscience, Lincoln, NE).

\subsection{Electron Microscopy}

EXO were fixed in $4 \%$ paraformaldehyde. The pellets were loaded onto carbon-coated formvar grids. The exosome sample-loaded grids were stained with saturated aqueous uranyl and then, examined with a JEOL 1200EX electron microscope at $60 \mathrm{kV}$.

\subsection{Animal Studies}

To examine the antitumor immunity conferred by the OVA- $\mathrm{T}_{\mathrm{EXO} / \mathrm{IL}-21}$ vaccine, WT B6 mice (6/group) were i.v. immunized with OVA- $\mathrm{T}_{\text {EXo/lL-21 }}$ cells or the control OVA- $\mathrm{T}_{\mathrm{EXO} / \mathrm{Null}}\left(1 \times 10^{6}\right.$ cells/mouse). Mice were i.v. injected with $0.5 \times 10^{6}$ BL6-10 ${ }_{\text {OVA }}$ cells six days post immunization. To assess therapeutic immunity of the Gag- $\mathrm{T}_{\mathrm{EXO} / \mathrm{IL}-21}$ vaccine, chronic infection $\mathrm{AdV}_{\mathrm{OVA}}-\mathrm{B} 6$ mice $(\mathrm{n}=6)$ with CTL inflation and functional exhaustion were first injected i.v. with $0.5 \times 10^{6}$ BL6-10 $0_{\text {Gag }}$ cells. Three days after tumor cell inoculation, AdVova-B6 mice were i.v. immunized with Gag- $\mathrm{T}_{\text {EXO/L-21 }}$ or the control Gag- $\mathrm{T}_{\text {EXO/Null }}$ cells $\left(1 \times 10^{6}\right.$ cells/mouse). The mice were sacrificed 3 weeks after tumor cell injection, and the lung metastatic B16 melanoma colonies were counted in a blind fashion. Metastatic B16 melanoma colonies on freshly isolated lungs appeared as black color foci that were easily distinguishable from normal lung tissues. Metastasis was also confirmed by histological examination.

\subsection{Statistical Analyses}

Statistical analyses were performed with the Mann-Whitney $U$ test using Prism 
software (GraphPad Software, San Diago, CA) to compare variables of different groups in animal studies or with the Student $t$ test to compare variables of different groups in flow cytometric analysis [32]. Unless stated otherwise, data are expressed as mean (with $\mathrm{SD}$ ). A value of $p<0.05$ was considered statistically significant.

\section{Results}

\subsection{Preparation of the Transgene IL-21-Engineered T Cell-Based OVA-T $\mathrm{T}_{\text {EXo/LL-21 }}$ Vaccine}

We constructed a replication-deficient transgene IL-21-expressing recombinant adenovirus $\mathrm{AdV}_{\mathrm{IL}-21}$ by recombinant DNA technology as we described in MATERIALS \& METHODS (Figure 1(a)) [18] [32]. B6 mouse dendritic cells were generated by culturing B6 mouse bone marrow cells in the culture medium containing GM-CSF and IL-4 for six days, pulsed with OVA for overnight and termed $\mathrm{DC}_{\mathrm{OVA}}$ [18] [32]. OVA-specific exosomes $\left(\mathrm{EXO}_{\mathrm{OVA}}\right)$ were purified from $\mathrm{DC}_{\mathrm{OVA}}$ culture supernatants by ultracentrifugation, and analyzed by electron microscopy and Western blotting analyses, respectively. We demonstrated that $\mathrm{EXO}_{\mathrm{OVA}}$ had exosomal "saucer" or round shape with $50-90 \mathrm{~nm}$ in diameter (Figure 1(b)) and contained EXO-associated proteins such as CD9 and LAMP-1 (Figure 1(c)) [37]. We infected the OVA- $\mathrm{T}_{\mathrm{EXO}}$ cells [32] with $\mathrm{AdV}_{\mathrm{IL}-21}$ to generate a transgene IL-21-engineered $\mathrm{T}$ cell-based vaccine, OVA- $\mathrm{T}_{\text {EXO/IL-21 }}$. IL-21 secretion in OVA- $\mathrm{T}_{\mathrm{EXO} / \mathrm{IL}-21}$ culture supernatants was estimated to be $\sim 200 \mathrm{pg} / \mathrm{ml}$ using IL-21 ELISA kit. In contrast, there was no IL-21 detected in OVA-T $\mathrm{T}_{\mathrm{EXO}}$ culture supernatants.

\subsection{OVA-T $\mathrm{T}_{\mathrm{Exo} / \mathrm{IL}-21}$ Vaccine Stimulates OVA-Specific CTL Responses in Wild-Type C57BL/6 Mice}

To examine the immunogenicity, we i.v. immunized $\mathrm{B} 6$ mice with OVA- $\mathrm{T}_{\mathrm{EXO} / \mathrm{IL}-21}$ or the control OVA- $\mathrm{T}_{\mathrm{EXO} / \mathrm{Null}}$ vaccine. We demonstrated that both OVA- $\mathrm{T}_{\mathrm{EXO} / \mathrm{IL}-21}$

(a)

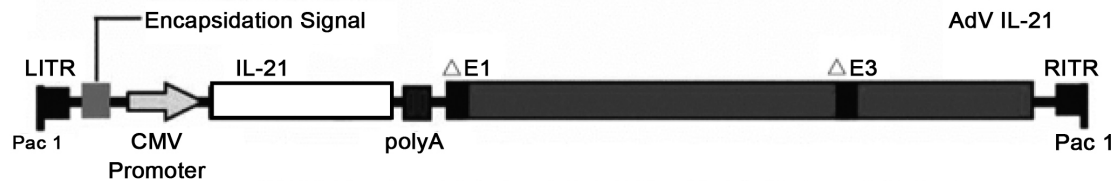

(b)

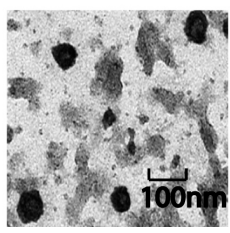

(c)

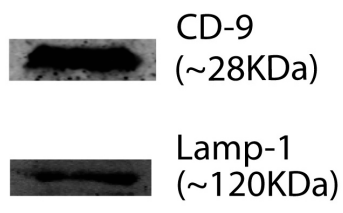

Figure 1. (a) Schematic representation of adenoviral (AdV) vector $A_{d V} V_{\text {IL-21 }}$. The E1/E3 depleted replication-deficient $\mathrm{AdV}$ is under the regulation of the cytomegalovirus (CMV) early promoter. ITR, inverted terminal repeat. (b) Electron micrograph of $\mathrm{EXO}_{\mathrm{OVA}}$. Bar, $100 \mathrm{~nm}$. (c) Western blot analysis of Western blot analysis of $\mathrm{EXO}_{\mathrm{OVA}}$ for expression of EXO markers CD9 and LAMP-1. 
and control OVA- $\mathrm{T}_{\text {EXO/Null }}$ vaccines stimulated comparable OVA-specific CTL responses (Figure 2(a)). To assess, whether these CTLs are of functional effect, we challenged immunized mice with OVA-expressing BL6-10 ${ }_{\mathrm{OVA}}$ tumor cells and examined its protective immunity against lung BL6-10 $0_{\mathrm{OVA}}$ tumor metastases. We showed that OVA- $\mathrm{T}_{\mathrm{EXO} / \mathrm{IL}-21}$ or the control OVA- $\mathrm{T}_{\mathrm{EXO} / \mathrm{Null}}$ vaccine induced complete protection from lung tumor metastases in all 6/6 mice (Figure 2(b) \& Figure $2(\mathrm{c})$ ), indicating that $\mathrm{OVA}-\mathrm{T}_{\mathrm{EXO} / \mathrm{IL}-21}$ vaccine stimulates comparable CTL responses compared to the control OVA- $\mathrm{T}_{\text {ExO }}$ vaccine in wild-type $\mathrm{B} 6$ mice.

\subsection{OVA-Expressing Adenovirus Induces an OVA-Specific Chronic Infection in Mice with CTL Exhaustion}

We previously found that infection of $\mathrm{B} 6$ mice with $\mathrm{AdV}_{\mathrm{OVA}}$, led to establishment of an OVA-specific chronic infection mouse model with OVA-specific CTL inflation and exhaustion [18]. To develop acute and chronic infection models, B6 mice were i.v. infected with OVA-expressing recombinant rLmOVA bacteria and $\mathrm{AdV}_{\mathrm{OVA}}$, respectively, followed by the kinetic analysis of OVA-specific CTL responses [18]. We demonstrated that $\mathrm{AdV}_{\mathrm{OVA}}$ infection resulted in OVA-specific memory $\mathrm{CD}^{+} \mathrm{T}$ cell inflation, when compared to CTLs developed in rLmOVA-immunized mice (Figure 3(a)), suggesting that rLmOVA induces an acute infection, while $\mathrm{AdV}_{\text {OVA }}$ induces a chronic infection with $\mathrm{CD} 8^{+} \mathrm{CTL}$ inflation [18] [19]. To confirm it, the phenotypes of OVA-specific memory CTLs were analyzed by flow cytometry. We demonstrated that memory CTLs expressed cell

(a)

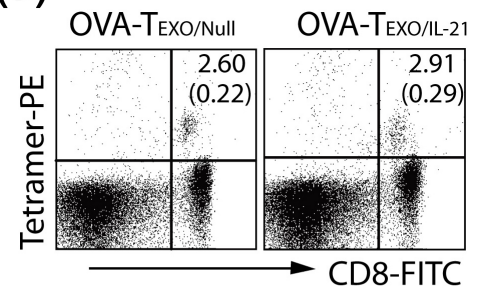

(b)

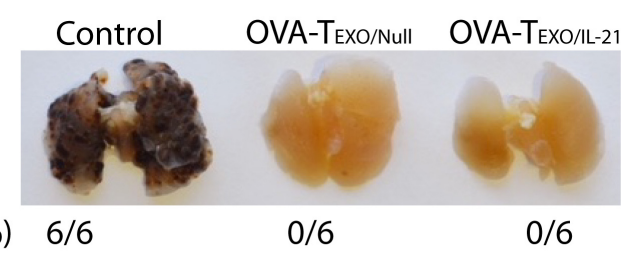

Tumor bearing mice(\%) $\quad 6 / 6$

Mean of metastatic $225 \pm 21$ tumor colonies
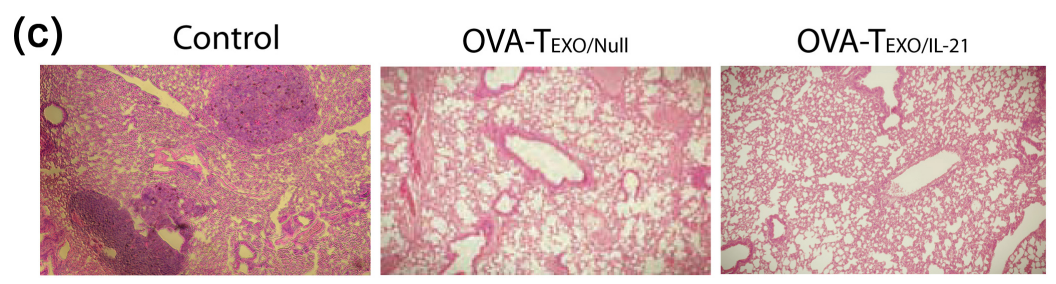

Figure 2. $A d V_{\text {IL-21 }}$ does not enhance OVA- $\mathrm{T}_{\mathrm{EXO}}$ vaccine immunity in wild-type (WT) B6 mice. (a) WT B6 mice $(\mathrm{n}=6)$ were injected with OVA- $\mathrm{T}_{\text {EXO/Null }}$ or OVA- $\mathrm{T}_{\text {EXO/IL-21. }}$ Six days after the injection, blood samples were collected, stained with FITC-CD8 Ab and PE-tetramer, and then analyzed by flow cytometry. The percentages of tetramer ${ }^{+} \mathrm{CD} 8^{+} \mathrm{T}$ cells in the total CD8 ${ }^{+} \mathrm{T}$ cell population are indicated. (b) WT B6 mice were immunized with OVA- $\mathrm{T}_{\mathrm{EXO} / \mathrm{Null}}$ or OVA- $\mathrm{T}_{\mathrm{EXO} / \mathrm{IL}-21}$, followed by injection with $\mathrm{BL}_{6-10 / 0 \mathrm{OVA}}$ tumor cells 6 day later. Mice lungs were collected at 21 days after the tumor cell injection. Metastatic tumor colonies in lung tissues were counted. (c) The lung tissues of immunized mice were fixed in 10\% neutral-buffered formalin and then embedded in paraffin. Tissue sections were stained with $\mathrm{H} \& \mathrm{E}$ and examined by microscopy. Magnification, $\times 100$. One representative experiment of two is shown. 

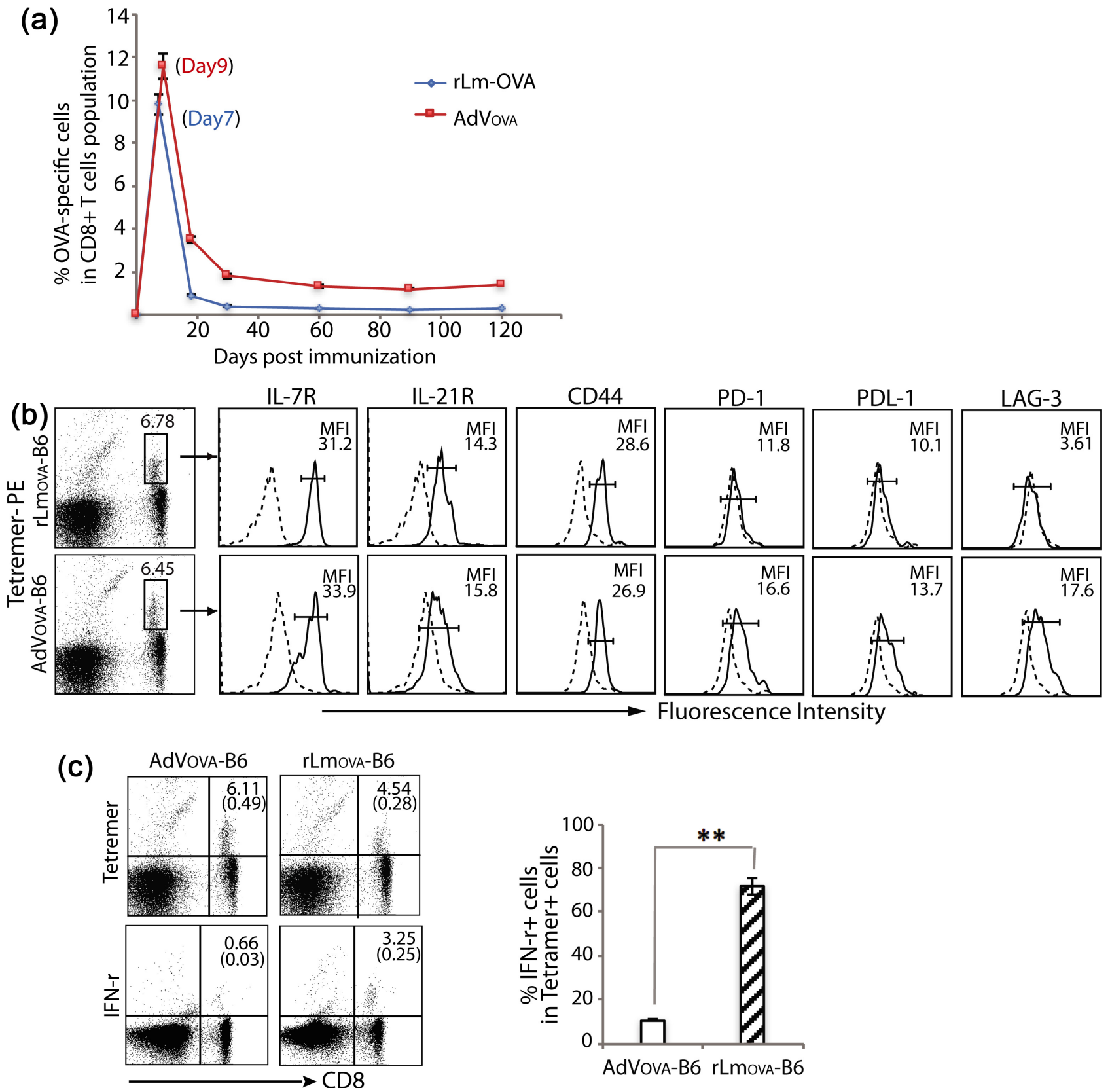

Figure 3. AdVova induces chronic infection in B6 mice. (a) OVA-specific CTL responses were analyzed at the indicated days post-AdVova or -rLmOVA infection by flow cytometry $(n=4)$. (b) Sixty days after the infection, flow cytometric analyses were performed. PE-tetramer and FITC-CD8 double positive cells were gated (rectangle) for further assessment of the expression of the indicated molecules (solid lines on the right). Mean fluorescence intensity (MFI) values are indicated in each panel. Dotted lines represent isotype controls. (c) Splenocytes were stained with PE-tetramer and FITC-CD8 or permeabilized for the assessment of intracellular IFN- $\gamma$ by flow cytometry. The value in each panel represents the percentage of $\mathrm{CD} 8^{+} \mathrm{T}$ cells producing IFN- $\gamma$ in the total $\mathrm{CD}^{+} \mathrm{T}$-cell population. ${ }^{* *} p<0.01$. One representative experiment of two is shown.

surface T-cell memory markers IL-7R and CD44 as well as IL-21R sixty days after infection in both $\mathrm{AdV}_{\mathrm{OVA}}-\mathrm{B} 6$ and rLmOVA-B6 mice (Figure 3(b)). Importantly, we also found that these CTLs developed in $\mathrm{AdV}_{\mathrm{OVA}_{\mathrm{A}}}$-immunized mice up-regulated inhibitory molecules, such as PD-1, PD-L1 and LAG-3, when compared to CTLs developed in rLmOVA-immunized mice (Figure 3(b)), 
indicating that these CTLs may be exhausted. To further confirm it, we assessed the functional effect (expression of the effector cytokine IFN- $\gamma$ ) of these CTLs by flow cytometry. We showed that $\sim 72 \%$ OVA-specific CTLs were IFN- $\gamma$ positive in rLmOVA-B6 mice, compared to only $\sim 10 \%$ OVA-specific CTLs were IFN- $\gamma$ positive in rLmOVA-B6 mice (Figure $3(\mathrm{c})$ ), thus confirming that those OVA-specific CTLs in $\mathrm{AdV}_{\mathrm{OVA}^{-}}-\mathrm{B} 6$ mice are exhausted CTLs [18] [19].

\subsection{The OVA- $\mathrm{T}_{\mathrm{EXo} / \mathrm{IL}-21}$ Vaccine Converts CTL Exhaustion in Chronic Infection}

We examined in our next set of experiments, whether the OVA- $\mathrm{T}_{\mathrm{EXO} / \mathrm{IL}-21}$ vaccine converts CTL exhaustion in chronic infection. The $\mathrm{AdV}_{\mathrm{OVA}^{-}} \mathrm{B} 6$ mice were boosted with OVA- $\mathrm{T}_{\mathrm{EXO} / \mathrm{IL}-21}$ and the control OVA- $\mathrm{T}_{\mathrm{EXO} / \mathrm{Null}}$ vaccine. Four days after the boost, cell proliferation and intracellular IFN- $\gamma$ expression of OVA-specific CTLs were assessed by flow cytometry. We demonstrated that there were $\sim 6$-fold $\left(5.20 \%\right.$ vs $0.81 \%$ ) of CTL increase in OVA- $\mathrm{T}_{\text {EXO/IL-21 }}$-boosted mouse peripheral blood, which is more than $\sim 3$-fold of CTL increase in the control OVA-T $\mathrm{T}_{\mathrm{EXO} / \mathrm{Null}}$-boosted mouse peripheral blood at day 4 after the boost (Figure $4(\mathrm{a})$ ), indicating that OVA- $\mathrm{T}_{\text {EXO/IL-21 }}$ vaccine can more potently convert CTL exhaustion by significantly stimulating the proliferation of previously exhausted CTLs. We next assessed expression of an effector T cell cytokine, IFN- $\gamma$, in exhausted CTLs on a "per-cell" basis by intracellular staining of T cell IFN- $\gamma$. We demonstrated that only $\sim 20 \%$ of OVA-specific CTLs were IFN- $\gamma$ positive in $\mathrm{AdV}_{\mathrm{OVA}^{-}}-\mathrm{B} 6$ mice (Figure 4(b)). In OVA- $\mathrm{T}_{\text {EXO/Null }}{ }^{-}$and OVA- $\mathrm{T}_{\mathrm{EXO} / \mathrm{IL}-21^{-}}$-boosted $\mathrm{AdV}_{\mathrm{OVA}_{\mathrm{A}}}-\mathrm{B} 6$ mice, however, we found $\sim 60 \%$ and $\sim 75 \%$ of IFN- $\gamma$-producing CTLs in the total OVA-specific CTLs, respectively (Figure 4(b)), confirming that OVA- $\mathrm{T}_{\mathrm{EXO} / \mathrm{IL}-21}$ vaccine more potently converts CTL exhaustion in chronic infection by not only increasing the number of CTLs, but also restoring CTL functional effect.

\subsection{OVA-Texo Converts CTL Exhaustion through the Activation of the mTORC1 Pathway}

We previously showed that the OVA- $\mathrm{T}_{\text {ExO }}$ vaccine rescued exhausted CTLs in chronic infection via its CD40L signaling, inducing the activation of the mTORC1 pathway [18]. Four days after the boost, cell phenotypes of the OVA-specific CTLs were assessed by flow cytometry to examine, whether the OVA- $\mathrm{T}_{\mathrm{EXO} / \mathrm{L}-21}$ vaccine activates the mTORC1 pathway. We analyzed CTLs for the phosphorylation status of mTORC1-regulated EIF4E (pEIF4E) and for the intracellular expression of the transcription factor T-bet by flow cytometry. We determined that OVA-specific CTLs up-regulated levels of phospho-EIF4E and T-bet in OVA- $\mathrm{T}_{\text {EXO/Null }}$-boosted $\mathrm{AdV}_{\mathrm{OVA}^{-}}-\mathrm{B} 6$ mice (Figure 4(a)), which was consistent with our previous report [18]. Interestingly, the intracellular expression of pEIF4E and T-bet in OVA-specific CTLs was significantly higher in the OVA- $\mathrm{T}_{\text {EXO/IL-21 }}$-boosted $\mathrm{AdV}_{\text {OVA }}$-B6 mice than that in the OVA- $\mathrm{T}_{\text {EXO/Null }}$-boosted $\mathrm{AdV}_{\mathrm{OVA}_{\mathrm{A}}} \mathrm{B} 6$ mice (pEIF4E, $p=0.02$; T-bet, $p=0.001$ ) (Figure 4(a)), confirming 


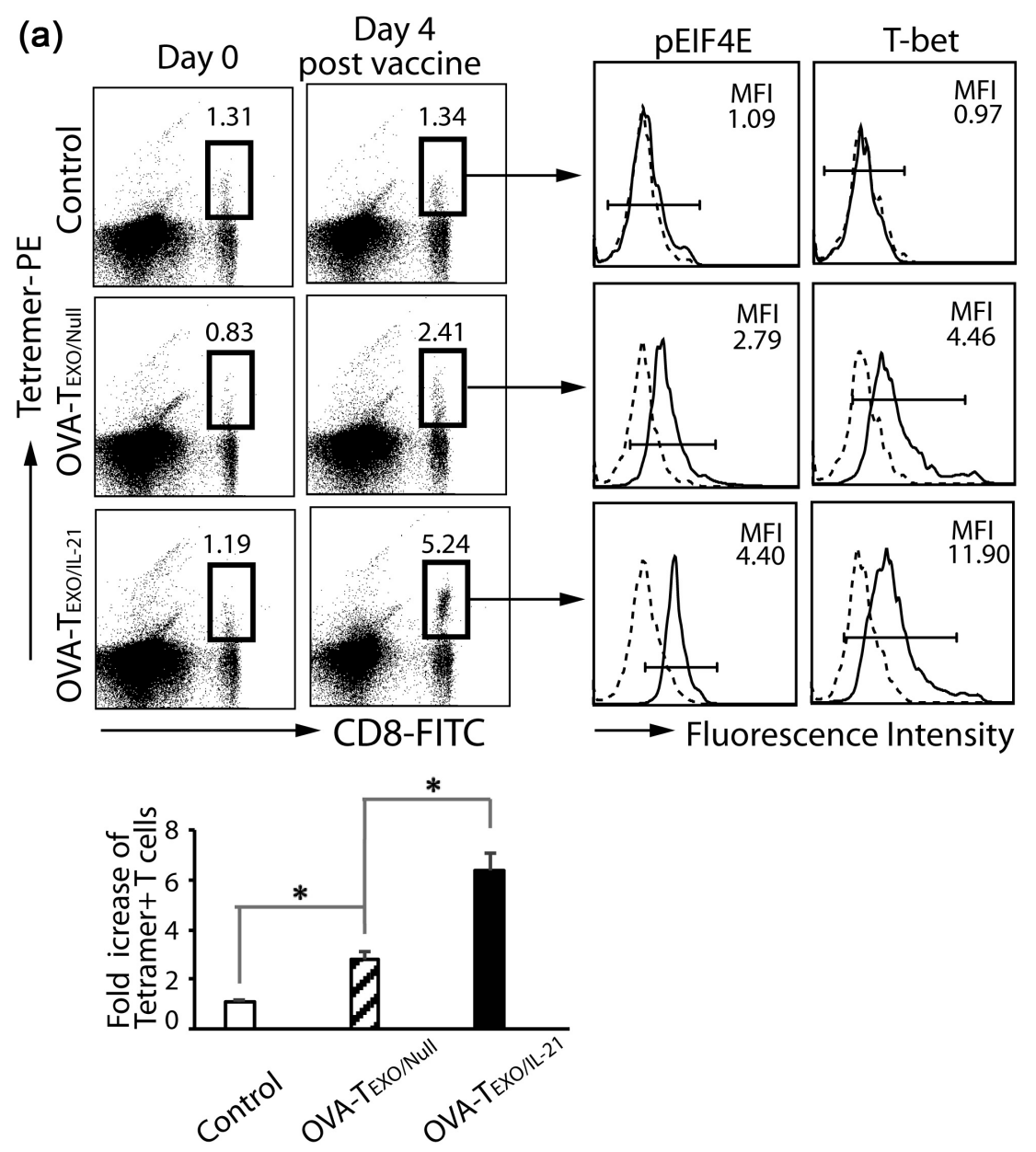

(b)

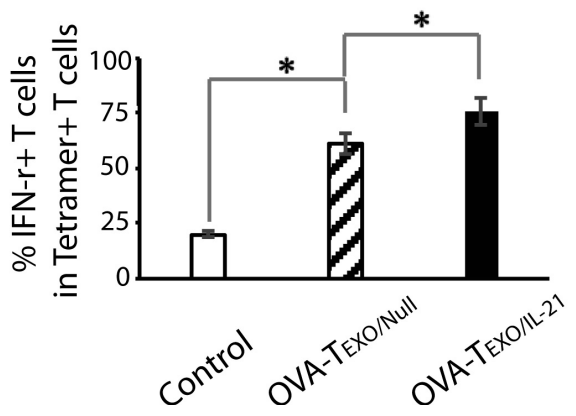

Figure 4. $\mathrm{AdV}_{\mathrm{IL}-21}$ enhance the capability of OVA-T $\mathrm{T}_{\mathrm{EXo}}$ vaccine in converting CTL exhaustion. AdVova-infected $\mathrm{B} 6$ mice $(\mathrm{n}=5)$ were immunized with $\mathrm{OVA}-\mathrm{T}_{\mathrm{EXO} / \mathrm{Null}}$ or OVA- $\mathrm{T}_{\mathrm{EXO} / \mathrm{IL}-21}$ at day 60 after the infection. (a) One day prior to (day 0 ) and 4 days post the immunization, periphery blood samples were analyzed for OVA-specific CTL responses by flow cytometry. The value in each panel represents a percentage of PE-tetramer-positive $\mathrm{CD} 8^{+} \mathrm{T}$ cells in the total peripheral $\mathrm{CD} 8^{+} \mathrm{T}$ cell population. Four days after immunization, mouse splenocytes were stained with PE-Tetramer, FITC-CD8, and PE-Cy5-labeled Abs. The tetramer ${ }^{+} \mathrm{CD}^{+}{ }^{+} \mathrm{T}$ cells were gated and assessed for expression of pelF4E and T-bet (solid lines). MFI values are indicated in each panel. The fold increases (\% Tetramer ${ }^{+} \mathrm{T}$ cells on day 4 post vaccine/\% Tetramer $^{+} \mathrm{T}$ cells on day 0 ) of tetramer ${ }^{+} \mathrm{CD}^{+} \mathrm{T}$ cells are indicated in the graph. (b) Splenocytes were permeabilized for the assessment of intracellular IFN- $\gamma$ by flow cytometry at day 4 after immunization. ${ }^{*} p<$ 0.05 . One representative experiment of two is shown. 
that OVA- $\mathrm{T}_{\text {EXO/IL-21 }}$ vaccine converts CTL exhaustion mostly through the activation of the mTORC1 pathway by both CD40L and IL-21 signaling.

\subsection{The Gag-T $\mathrm{T}_{\mathrm{Exo} / \mathrm{IL}-21}$ Vaccine Induces Gag-Specific Therapeutic Immunity in Chronic Infection Model}

To assess a potential therapeutic immunity of the Gag- $\mathrm{T}_{\mathrm{EXO} / \mathrm{IL}-21}$ vaccine in chronic infection, $A d V_{\text {OVA }}-B 6$ mice with chronic infection of $A d V_{O V A}$ were first i.v. injected with Gag-expressing BL6-10 $0_{\text {Gag }}$ melanoma cells, and four days post B16 melanoma cell challenge, mice were i.v. immunized with the Gag- $\mathrm{T}_{\mathrm{EXO} / \mathrm{IL}-21}$ or the control Gag- $\mathrm{T}_{\text {ExO/Null }}$ vaccine (Figure 5(a)). Seventeen days later, mouse lung tissues were collected for histopathological examination (Figure 5(a)). Importantly, the Gag- $\mathrm{T}_{\mathrm{EXO} / \mathrm{IL}-21}$ vaccine demonstrated a complete eradication of established $\mathrm{BL} 6-10_{\text {Gag }}$ lung metastases in $5 / 6 \mathrm{AdV}_{\mathrm{OVA}_{\mathrm{A}}}-\mathrm{B} 6$ mice, thus stimulating more efficient therapeutic immunity against Gag-expressing BL6-10 $0_{\text {Gag }}$ melanoma than the control Gag- $\mathrm{T}_{\text {ExO/Null }}$ vaccination (Figure 5(b)). Our data indicate that Gag- $\mathrm{T}_{\text {EXO/L-21 }}$ vaccine is capable of inducing potent therapeutic immunity against established Gag-expressing tumors in the presence of chronic infection.

\section{Discussion}

The inhibitory PD-1 molecule was originally found on active $\mathrm{T}$ cells following TCR engagement and became a $\mathrm{T}$ cell-intrinsic mechanism for negatively regulating CTL responses [38] [39]. In chronic infection, PD-1 expression is sustained on CTLs due to persistent antigen stimulation. Expression of PD-1 suppresses T

(a)

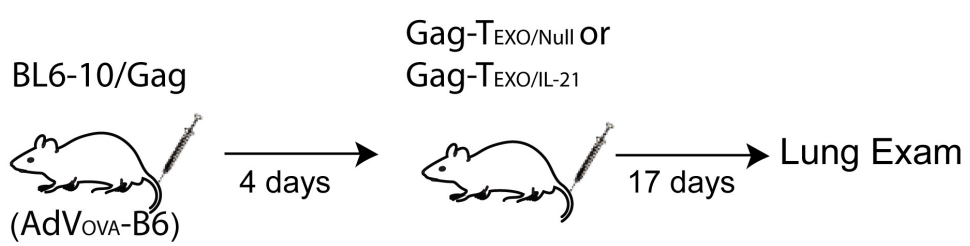

(b)

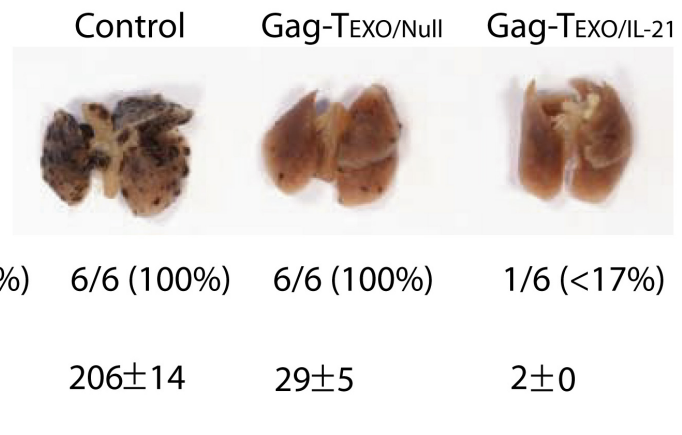

Figure 5. Gag- $\mathrm{T}_{\mathrm{EXO} / \mathrm{IL}-21}$ vaccine stimulates enhanced antitumor immunity in chronic infection mice. (a) Experimental set-up to examine the therapeutic antitumor immunity of $\mathrm{T}_{\text {EXo }}$ vaccines. Chronic AdVova-B6 mice $(\mathrm{n}=6)$ were i.v. injected with BL6-10 ${ }_{\text {OVA }}$ cells. Four days after tumor challenge, mice were vaccinated with Gag- $\mathrm{T}_{\text {EXO/Null, }}$ Gag- $\mathrm{T}_{\text {EXO/IL-21 }}$ or control ConA-T. The mice were sacrificed 3 weeks after tumor cell challenge. (b) The average number of lung metastatic tumor colonies was counted. ${ }^{\star} p<0.05$ versus cohorts of ConA-T cells. One representative experiment of three is shown. 
cell functions through inhibiting TCR signaling by recruiting phosphatases [40] [41] and modulating the mTORC1 pathway responsible for $\mathrm{T}$ cell proliferation and effector function [38] [39]. Later, expression of other inhibitory molecules such as LAG-3 and TIM-3 has also been found on exhausted CTLs [42]. It has been demonstrated that PD-1 blockade rescued exhausted CTLs in chronic viral infection [17]. An enhanced effect on conversion of CTL exhaustion was observed upon combination treatments with antagonists of various inhibitory molecules, such as PD-1, LAG-3 and Tim-3 [42] [43]. In addition to blockade therapies, costimulatory signaling, such as 41BB-, OX40- and CD27-mediated costimulation also synergized with PD-L1 blockade by forcing exhausted CTLs to exit quiescence [4] [44] [45]. Moreover, costimulating CD40L signaling has been shown to assure $\mathrm{T}$ cell activation by recruiting tumor necrosis factor (TNF) receptor-associated factor (TRAF), which leads to the activation of the mTORC1 pathway [46]. Consistent with this, it has recently been demonstrated that CD40 agonist enhances PD-1 blockade's effect in rescuing exhausted CTLs in chronic infection [19].

IL-21 belongs to the common $\gamma$-chain cytokine family and is closely related to another family member, IL-2, which is encoded upstream of IL-21 on chromosome 3 [47]. IL-21 binds to a heterodimeric receptor CD123 encoded on chromosome 7 [48], which is widely expressed by B cells, natural killer cells, DCs, macrophages and T cells [47] [48]. The IL-21 cytokine was originally found to be produced by $\mathrm{CD}^{+} \mathrm{T}$ cells [20] and to serve as a "third" signal, functioning in cooperation with TCR ligation and costimulation, to trigger $\mathrm{CD}^{+} \mathrm{T}$ cell responses [21]. IL-21 promotes CTL activation and survival by inducing signaling through the phosphatidylinositol-3 kinase (PI3K) and the mTORC1-regulated T-bet pathway [49] [50]. In addition, IL-21 also upregulates granzyme-B expression in CTLs [51] and triggers proliferation of B cells and NK cells [52]. Recently, it has been shown that IL-21 plays a significant role in controlling chronic LCMV infection by rescuing exhausted CTL via diminishing their exhaustion phenotype and maintaining their ability to proliferate [22] [23] [24]. IL-21 also restricts virus-driven regulatory $\mathrm{T}$ cell expansion in chronic LCMV infection [53], enhances cytolytic and virus-controlling abilities of HIV-specific CTLs in vitro [25] [26], and enhances virus control in immunodeficiency virus -infected rhesus macaques or in HCV- and HIV-1-infected patients [4] [7] [28] [54] [55].

We previously developed a novel OVA-specific EXO-targeted $\mathrm{T}$ cell-based OVA- $\mathrm{T}_{\text {EXO }}$ vaccine by using non-specific polyclonal $\mathrm{T}$ cells with the uptake of OVA-specific DC-released EXO [29]. We found that the OVA-Texo vaccine was able to directly stimulate potent OVA-specific CTL responses by counteracting $\mathrm{CD}^{+} 25^{+} \mathrm{FoxP}^{+}$Treg-induced CTL suppression [29] [30]. We also demonstrated that the 4-1BBL-expressing OVA- $\mathrm{T}_{\mathrm{ExO}}$ vaccine triggered an enhanced therapeutic immunity in WT B6 mice [32] and induced an efficient conversion of CTL exhaustion in chronic infection model via the CD40L-initiated signaling through the mTORC1 pathway [18]. In this study, we generated new OVA- $\mathrm{T}_{\mathrm{EXO} / \mathrm{IL}-21}$ and 
Gag- $\mathrm{T}_{\mathrm{EXO} / \mathrm{IL}-21}$ vaccines, expressing IL-21, by infecting the above 41BBL-expressing OVA- $\mathrm{T}_{\text {EXO }}$ and Gag- $\mathrm{T}_{\text {EXo }}$ cells with $\mathrm{AdV}_{\mathrm{IL}-21}$, as previously described [32]. We assessed the effectiveness of the OVA- $\mathrm{T}_{\mathrm{EXO} / \mathrm{IL}-21}$ vaccine in the conversion of CTL exhaustion and examined the effectiveness of the Gag- $\mathrm{T}_{\mathrm{EXO} / \mathrm{IL}-21}$ vaccine in therapeutic immunity against Gag-expressing tumor in chronic infection. We discovered that in chronic infection, the OVA- $\mathrm{T}_{\mathrm{EXO} / \mathrm{IL}-21}$ vaccination more strongly rescued CTL exhaustion than the OVA- $\mathrm{T}_{\text {EXo/Null }}$ vaccine. In addition, we also found that OVA-T $\mathrm{TXX}_{\mathrm{EX} / \mathrm{L}-21}$-boosted CTLs strongly up-regulated phosphorylation of

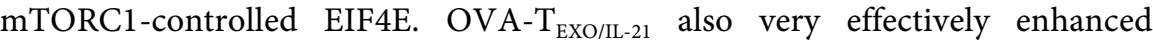
mTORC1-controlled expression of $\mathrm{T}$-bet that regulates $\mathrm{T}$ cell activation. These OVA- $\mathrm{T}_{\mathrm{EXO} / \mathrm{IL}-21}$-induced responses were significantly stronger than OVA- $\mathrm{T}_{\mathrm{EXO}}{ }^{-}$ boosted ones. It has been shown that IL-21 promotes CTL survival via activation of the PI3K signaling cascade [49]. Our data showing that OVA-T $\mathrm{EXO}_{\text {IL-21 }}$ vaccination more strongly rescued CTL exhaustion than the OVA- $\mathrm{T}_{\mathrm{EXO}}$ one indicates that the IL-21 signaling of OVA- $\mathrm{T}_{\mathrm{EXO} / \mathrm{IL}-21}$ vaccine plays an important role in conversion of CTL exhaustion via the activation of the mTORC1 pathway in chronic infection. Our data thus provide the first evidence that our novel $\mathrm{T}$ cell-based vaccine is capable of converting CTL exhaustion in chronic infection via its CD40L and IL-21 signaling through the mTORC1 pathway.

$\mathrm{CD}^{+}$CTLs are important effector $\mathrm{T}$ cells capable of directly destroying HIV-1-infected cells, and their activity correlates with acute viral control and long-term nonprogression [56] [57] [58] [59]. CD8 ${ }^{+}$CTLs play a critical role in controlling HIV-1 proliferation and disease progression even in the absence of neutralizing antibodies [60] [61]. Stimulation of HIV-1-specific CTLs has been also reported to facilitate elimination of latent viral reservoirs [62] [63]. We originally generated HIV-1 Gag-specific Gag- $\mathrm{T}_{\mathrm{EXO}}$ vaccine by using polyclonal ConA-T cells with the uptake of Gag-specific DC-released EXO, and demonstrated that Gag- $\mathrm{T}_{\text {EXo }}$ stimulated Gag-specific CTL responses in transgenic HLA-A2 mice [31]. We also generated a 4-1BBL-expressing Gag- $\mathrm{T}_{\text {EXo }}$ vaccine capable of triggering more efficient CTL responses and therapeutic immunity against Gag-expressing tumor challenges than the original Gag- $\mathrm{T}_{\mathrm{ExO}}$ vaccine [32]. In this study, we have generated a new Gag- $\mathrm{T}_{\mathrm{EXO} / \mathrm{IL}-21}$ vaccine engineered to express IL-21 by infection of the 41BBL-expressing Gag- $\mathrm{T}_{\mathrm{EXO}}$ cells with $\mathrm{AdV}_{\mathrm{IL}-21}$ as [32], and demonstrated that the Gag- $\mathrm{T}_{\mathrm{EXO} / \mathrm{IL}-21}$ vaccine triggered more effective therapeutic immunity against established Gag-specific BL6-10 $0_{\text {Gag }}$ melanoma lung metastases in chronic infection. We expect that combinations of similarly designed vaccines with blockades against various inhibitory molecules, such as PD-1, TIM-3 and LAG-3, may become new startegies for combined immunotherapies to covert CTL exhaustion in chronic infections such as HIV-1.

Taken together, our data demonstrate that our novel transgene IL-21-engineered $\mathrm{T}$ cell-based vaccine OVA- $\mathrm{T}_{\mathrm{EXO} / \mathrm{IL}-21}$ is capable of strongly converting the exhaustion of CD40-expressing CTLs in chronic infection via the activation of the mTORC1 pathway caused by endogenous CD40L- and transgene IL-21-triggered 
signals. Therefore, this study is likely to have a strong impact on developing new therapeutic vaccines that might be used as monotherapies or in combination with other HIV-1 blockades for treating immune deficiency syndrome patients.

\section{Acknowledgements}

We thank Mark Boyd for help in flow cytometric analyses. This work was supported by a Canadian Institute of Health Research (CIHR) grant (OCH 126276).

\section{Conflicts of Interest}

The authors declare no conflict of interest.

\section{References}

[1] Wherry, E.J. and Ahmed, R. (2004) Memory CD8 T-Cell Differentiation during Viral Infection. Journal of Virology, 78, 5535-5545. https://doi.org/10.1128/JVI.78.11.5535-5545.2004

[2] Ahmed, K.A., Wang, L., Griebel, P., Mousseau, D.D. and Xiang, J. (2015) Differential Expression of Mannose-6-Phosphate Receptor Regulates T Cell Contraction. Journal of Leukocyte Biology, 98, 313-318. https://doi.org/10.1189/jlb.2HI0215-049RR

[3] Wherry, E.J. (2011) T Cell Exhaustion. Nature Immunology, 12, 492-499. https://doi.org/10.1038/ni.2035

[4] Buchan, S.L., Manzo, T., Flutter, B., Rogel, A., Edwards, N., Zhang, L., et al. (2015) OX40- and CD27-Mediated Costimulation Synergizes with Anti-PD-L1 Blockade by Forcing Exhausted CD8 ${ }^{+} \mathrm{T}$ Cells To Exit Quiescence. Journal of Immunology, 194, 125-133. https://doi.org/10.4049/jimmunol.1401644

[5] Fuller, M.J., Khanolkar, A., Tebo, A.E. and Zajac, A.J. (2004) Maintenance, Loss, and Resurgence of $\mathrm{T}$ Cell Responses during Acute, Protracted, and Chronic Viral Infections. Journal of Immunology, 172, 4204-4214.

https://doi.org/10.4049/jimmunol.172.7.4204

[6] Anderson, A.C. (2012) Editorial: Tim-3 Puts on the Brakes. Journal of Leukocyte Biology, 91, 183-185. https://doi.org/10.1189/jlb.0811423

[7] Pallikkuth, S., Rogers, K., Villinger, F., Dosterii, M., Vaccari, M., Franchini, G., et al. (2011) Interleukin-21 Administration to Rhesus Macaques Chronically Infected with Simian Immunodeficiency Virus Increases Cytotoxic Effector Molecules in $\mathrm{T}$ Cells and NK Cells and Enhances B Cell Function without Increasing Immune Activation or Viral Replication. Vaccine, 29, 9229-9238.

https://doi.org/10.1016/j.vaccine.2011.09.118

[8] Gallimore, A., Glithero, A., Godkin, A., Tissot, A.C., Pluckthun, A., Elliott, T., et al. (1998) Induction and Exhaustion of Lymphocytic Choriomeningitis Virus-Specific Cytotoxic T Lymphocytes Visualized Using Soluble Tetrameric Major Histocompatibility Complex Class I-Peptide Complexes. Journal of Experimental Medicine, 187, 1383-1393. https://doi.org/10.1084/jem.187.9.1383

[9] Zajac, A.J., Blattman, J.N., Murali-Krishna, K., Sourdive, D.J., Suresh, M., Altman, J.D., et al. (1998) Viral Immune Evasion Due to Persistence of Activated T Cells without Effector Function. Journal of Experimental Medicine, 188, 2205-2213. https://doi.org/10.1084/jem.188.12.2205

[10] Wherry, E.J., Blattman, J.N., Murali-Krishna, K., Van Der Most, R. and Ahmed, R. 
(2003) Viral Persistence Alters CD8 T-Cell Immunodominance and Tissue Distribution and Results in Distinct Stages of Functional Impairment. Journal of Virology, 77, 4911-4927. https://doi.org/10.1128/JVI.77.8.4911-4927.2003

[11] Brooks, D.G., Teyton, L., Oldstone, M.B. and Mcgavern, D.B. (2005) Intrinsic Functional Dysregulation of CD4 T Cells Occurs Rapidly Following Persistent Viral Infection. Journal of Virology, 79, 10514-10527. https://doi.org/10.1128/JVI.79.16.10514-10527.2005

[12] Blattman, J.N., Wherry, E.J., Ha, S.J., Van Der Most, R.G. and Ahmed, R. (2009) Impact of Epitope Escape on PD-1 Expression and CD8 T-Cell Exhaustion during Chronic Infection. Journal of Virology, 83, 4386-4394. https://doi.org/10.1128/JVI.02524-08

[13] Virgin, H.W., Wherry, E.J. and Ahmed, R. (2009) Redefining Chronic Viral Infection. Cell, 138, 30-50. https://doi.org/10.1016/j.cell.2009.06.036

[14] Althaus, C.L., Ganusov, V.V. and De Boer, R.J. (2007) Dynamics of CD8 ${ }^{+}$T Cell Responses during Acute and Chronic Lymphocytic Choriomeningitis Virus Infection. Journal of Immunology, 179, 2944-2951. https://doi.org/10.4049/jimmunol.179.5.2944

[15] Matloubian, M., Somasundaram, T., Kolhekar, S.R., Selvakumar, R. and Ahmed, R. (1990) Genetic Basis of Viral Persistence: Single Amino Acid Change in the Viral Glycoprotein Affects Ability of Lymphocytic Choriomeningitis Virus to Persist in Adult Mice. Journal of Experimental Medicine, 172, 1043-1048. https://doi.org/10.1084/jem.172.4.1043

[16] Matloubian, M., Kolhekar, S.R., Somasundaram, T. and Ahmed, R. (1993) Molecular Determinants of Macrophage Tropism and Viral Persistence: Importance of Single Amino Acid Changes in the Polymerase and Glycoprotein of Lymphocytic Choriomeningitis Virus. Journal of Virology, 67, 7340-7349.

[17] Barber, D.L., Wherry, E.J., Masopust, D., Zhu, B., Allison, J.P., Sharpe, A.H., et al. (2006) Restoring Function in Exhausted CD8 T Cells during Chronic Viral Infection. Nature, 439, 682-687. https://doi.org/10.1038/nature04444

[18] Wang, R., Xu, A., Zhang, X., Wu, J., Freywald, A., Xu, J., et al. (2017) Novel Exosome-Targeted T-Cell-Based Vaccine Counteracts T-Cell Anergy and Converts CTL Exhaustion in Chronic Infection via CD40L Signaling through the mTORC1 Pathway. Cellular \& Molecular Immunology, 14, 529-545. https://doi.org/10.1038/cmi.2016.23

[19] Xu, A., Wang, R., Freywald, A., Stewart, K., Tikoo, S., Xu, J., et al. (2017) CD40 Agonist Converting CTL Exhaustion via the Activation of the mTORC1 Pathway Enhances PD-1 Antagonist Action in Rescuing Exhausted CTLs in Chronic Infection. Biochemical and Biophysical Research Communications, 484, 662-667. https://doi.org/10.1016/j.bbrc.2017.01.172

[20] Leonard, W.J., Zeng, R. and Spolski, R. (2008) Interleukin 21: A Cytokine/Cytokine Receptor System that Has Come of Age. Journal of Leukocyte Biology, 84, 348-356. https://doi.org/10.1189/jlb.0308149

[21] Casey, K.A. and Mescher, M.F. (2007) IL-21 Promotes Differentiation of Naive CD8 $\mathrm{T}$ Cells to a Unique Effector Phenotype. The Journal of Immunology, 178, 7640-7648. https://doi.org/10.4049/jimmunol.178.12.7640

[22] Elsaesser, H., Sauer, K. and Brooks, D.G. (2009) IL-21 Is Required to Control Chronic Viral Infection. Science, 324, 1569-1572. https://doi.org/10.1126/science.1174182

[23] Yi, J.S., Du, M. and Zajac, A.J. (2009) A Vital Role for Interleukin-21 in the Control 
of a Chronic Viral Infection. Science, 324, 1572-1576.

https://doi.org/10.1126/science.1175194

[24] Frohlich, A., Kisielow, J., Schmitz, I., Freigang, S., Shamshiev, A.T., Weber, J., et al. (2009) IL-21R on T Cells Is Critical for Sustained Functionality and Control of Chronic Viral Infection. Science, 324, 1576-1580. https://doi.org/10.1126/science.1172815

[25] Chevalier, M.F., Julg, B., Pyo, A., Flanders, M., Ranasinghe, S., Soghoian, D.Z., et al. (2011) HIV-1-Specific Interleukin-21(+) CD4(+) T Cell Responses Contribute to Durable Viral Control through the Modulation of HIV-Specific CD8(+) T Cell Function. Journal of Virology, 85, 733-741. https://doi.org/10.1128/JVI.02030-10

[26] Parmigiani, A., Pallin, M.F., Schmidtmayerova, H., Lichtenheld, M.G. and Pahwa, S. (2011) Interleukin-21 and Cellular Activation Concurrently Induce Potent Cytotoxic Function and Promote Antiviral Activity in Human CD8 T Cells. Hum Immunol, 72, 115-123. https://doi.org/10.1016/j.humimm.2010.10.015

[27] Yue, F.Y., Lo, C., Sakhdari, A., Lee, E.Y., Kovacs, C.M., Benko, E., et al. (2010) HIV-Specific IL-21 Producing CD4+ T Cells Are Induced in Acute and Chronic Progressive HIV Infection and Are Associated with Relative Viral Control. The Journal of Immunology, 185, 498-506. https://doi.org/10.4049/jimmunol.0903915

[28] Feng, G., Zhang, J.Y., Zeng, Q.L., Jin, L., Fu, J., Yang, B., et al. (2013) HCV-Specific Interleukin-21+CD4+ T Cells Responses Associated with Viral Control through the Modulation of HCV-Specific CD8+ T Cells Function in Chronic Hepatitis C Patients. Molecules and Cells, 36, 362-367. https://doi.org/10.1007/s10059-013-0181-z

[29] Hao, S., Yuan, J. and Xiang, J. (2007) Nonspecific CD4(+) T Cells with Uptake of Antigen-Specific Dendritic Cell-Released Exosomes Stimulate Antigen-Specific CD8(+) CTL Responses and Long-Term T Cell Memory. Journal of Leukocyte Biology, 82, 829-838. https://doi.org/10.1189/jlb.0407249

[30] Hao, S., Liu, Y., Yuan, J., Zhang, X., He, T., Wu, X., et al. (2007) Novel Exosome-Targeted CD4+ T Cell Vaccine Counteracting CD4+25+ Regulatory $\mathrm{T}$ Cell-Mediated Immune Suppression and Stimulating Efficient Central Memory CD8+ CTL Responses. The Journal of Immunology, 179, 2731-2740. https://doi.org/10.4049/jimmunol.179.5.2731

[31] Wang, R.X.Y., Zhao, T., Tan, X., Xu, J. and Xiang, J. (2014) HIV-1 Gag-Specific Exosome-Targeted T Cell-Based Vaccine Stimulates Effector CTL Responses Leading to Therapeutic and Long-Term Immunity against Gag/HLA-A2-Expressing B16 Melanoma in Transgenic HLA-A2 mice. Trials in Vaccinology, 3, 19-25. https://doi.org/10.1016/j.trivac.2013.12.001

[32] Wang, R., Freywald, A., Chen, Y., Xu, J., Tan, X. and Xiang, J. (2015) Transgenic 4-1BBL-Engineered Vaccine Stimulates Potent Gag-Specific Therapeutic and Long-Term Immunity via Increased Priming of CD44(+)CD62L(high) IL-7R(+) CTLs with Up- and Downregulation of Anti- and Pro-Apoptosis Genes. Cellular \& Molecular Immunology, 12, 456-465. https://doi.org/10.1038/cmi.2014.72

[33] Xiang, J., Huang, H. and Liu, Y. (2005) A New Dynamic Model of CD8+ T Effector Cell Responses via CD4+ T Helper-Antigen-Presenting Cells. The Journal of Immunology, 174, 7497-7505. https://doi.org/10.4049/jimmunol.174.12.7497

[34] Nanjundappa, R.H., Wang, R., Xie, Y., Umeshappa, C.S., Chibbar, R., Wei, Y., et al. (2011) GP120-Specific Exosome-Targeted T Cell-Based Vaccine Capable of Stimulating DC- and CD4(+) T-Independent CTL Responses. Vaccine, 29, 3538-3547. https://doi.org/10.1016/j.vaccine.2011.02.095

[35] Nanjundappa, R.H., Wang, R., Xie, Y., Umeshappa, C.S. and Xiang, J. (2012) Novel 
CD8+ T Cell-Based Vaccine Stimulates Gp120-Specific CTL Responses Leading to Therapeutic and Long-Term Immunity in Transgenic HLA-A2 Mice. Vaccine, 30, 3519-3525. https://doi.org/10.1016/j.vaccine.2012.03.075

[36] Bevan, M.J. (2004) Helping the CD8(+) T-Cell Response. Nature Reviews Immunology, 4, 595-602. https://doi.org/10.1038/nri1413

[37] Xie, Y., Zhang, X., Zhao, T., Li, W. and Xiang, J. (2013) Natural CD8(+)25(+) Regulatory T Cell-Secreted Exosomes Capable of Suppressing Cytotoxic T Lymphocyte-Mediated Immunity against B16 Melanoma. Biochemical and Biophysical Research Communications, 438, 152-155. https://doi.org/10.1016/j.bbrc.2013.07.044

[38] Parry, R.V., Chemnitz, J.M., Frauwirth, K.A., Lanfranco, A.R., Braunstein, I., Kobayashi, S.V., et al. (2005) CTLA-4 and PD-1 Receptors Inhibit T-Cell Activation by Distinct Mechanisms. Molecular and Cellular Biology, 25, 9543-9553.

https://doi.org/10.1128/MCB.25.21.9543-9553.2005

[39] Patsoukis, N., Brown, J., Petkova, V., Liu, F., Li, L. and Boussiotis, V.A. (2012) Selective Effects of PD-1 on Akt and Ras Pathways Regulate Molecular Components of the Cell Cycle and Inhibit T Cell Proliferation. Science Signaling, 5, ra46. https://doi.org/10.1126/scisignal.2002796

[40] Sheppard, K.A., Fitz, L.J., Lee, J.M., Benander, C., George, J.A., Wooters, J., et al. (2004) PD-1 Inhibits T-Cell Receptor Induced Phosphorylation of the ZAP70/CD3zeta Signalosome and Downstream Signaling to PKCtheta. FEBS Letters, 574, 37-41. https://doi.org/10.1016/j.febslet.2004.07.083

[41] Yokosuka, T., Takamatsu, M., Kobayashi-Imanishi, W., Hashimoto-Tane, A., Azuma, M. and Saito, T. (2012) Programmed Cell Death 1 Forms Negative Costimulatory Microclusters that Directly Inhibit T Cell Receptor Signaling by Recruiting Phosphatase SHP2. The Journal of Experimental Medicine, 209, 1201-1217. https://doi.org/10.1084/jem.20112741

[42] Pauken, K.E. and Wherry, E.J. (2015) Overcoming T Cell Exhaustion in Infection and Cancer. Trends in Immunology, 36, 265-276. https://doi.org/10.1016/j.it.2015.02.008

[43] Jin, H.T., Anderson, A.C., Tan, W.G., West, E.E., Ha, S.J., Araki, K., et al. (2010) Cooperation of Tim-3 and PD-1 in CD8 T-Cell Exhaustion during Chronic Viral Infection. Proceedings of the National Academy of Sciences of the United States of America, 107, 14733-14738. https://doi.org/10.1073/pnas.1009731107

[44] Wang, C., Wen, T., Routy, J.P., Bernard, N.F., Sekaly, R.P. and Watts, T.H. (2007) 4-1BBL Induces TNF Receptor-Associated Factor 1-Dependent Bim Modulation in Human T Cells and Is a Critical Component in the Costimulation-Dependent Rescue of Functionally Impaired HIV-Specific CD8 T Cells. The Journal of Immunology, 179, 8252-8263. https://doi.org/10.4049/jimmunol.179.12.8252

[45] Vezys, V., Penaloza-Macmaster, P., Barber, D.L., Ha, S.J., Konieczny, B., Freeman, G.J., et al. (2011) 4-1BB Signaling Synergizes with Programmed Death Ligand 1 Blockade to Augment CD8 T Cell Responses during Chronic Viral Infection. The Journal of Immunology, 187, 1634-1642. https://doi.org/10.4049/jimmunol.1100077

[46] Elgueta, R., Benson, M.J., De Vries, V.C., Wasiuk, A., Guo, Y. and Noelle, R.J. (2009) Molecular Mechanism and Function of CD40/CD40L Engagement in the Immune System. Immunological Reviews, 229, 152-172. https://doi.org/10.1111/j.1600-065X.2009.00782.x

[47] Parrish-Novak, J., Dillon, S.R., Nelson, A., Hammond, A., Sprecher, C., Gross, J.A., et al. (2000) Interleukin 21 and Its Receptor Are Involved in NK Cell Expansion and Regulation of Lymphocyte Function. Nature, 408, 57-63. 
https://doi.org/10.1038/35040504

[48] Ozaki, K., Kikly, K., Michalovich, D., Young, P.R. and Leonard, W.J. (2000) Cloning of a Type I Cytokine Receptor Most Related to the IL-2 Receptor $\beta$ Chain. Proceedings of the National Academy of Sciences of the United States of America, 97, 11439-11444. https://doi.org/10.1073/pnas.200360997

[49] Ostiguy, V., Allard, E.L., Marquis, M., Leignadier, J. and Labrecque, N. (2007) IL-21 Promotes T Lymphocyte Survival by Activating the Phosphatidylinositol-3 Kinase Signaling Cascade. Journal of Leukocyte Biology, 82, 645-656.

https://doi.org/10.1189/jlb.0806494

[50] Sutherland, A.P.R., Joller, N., Michaud, M., Liu, S.M., Kuchroo, V.K. and Grusby, M.J. (2013) IL-21 Promotes CD8+ CTL Activity via the Transcription Factor T-Bet. The Journal of Immunology, 190, 3977-3984.

https://doi.org/10.4049/jimmunol.1201730

[51] Zeng, R., Spolski, R., Finkelstein, S.E., Oh, S., Kovanen, P.E., Hinrichs, C.S., et al. (2005) Synergy of IL-21 and IL-15 in Regulating CD8+ T Cell Expansion and Function. The Journal of Experimental Medicine, 201, 139-148.

https://doi.org/10.1084/jem.20041057

[52] Habib, T., Nelson, A. and Kaushansky, K. (2003) IL-21: A Novel IL-2-Family Lymphokine that Modulates B, T, and Natural Killer Cell Responses. The Journal of Allergy and Clinical Immunology, 112, 1033-1045. https://doi.org/10.1016/j.jaci.2003.08.039

[53] Schmitz, I., Schneider, C., Frohlich, A., Frebel, H., Christ, D., Leonard, W.J., et al. (2013) IL-21 Restricts Virus-Driven Treg Cell Expansion in Chronic LCMV Infection. PLOS Pathogens, 9, e1003362. https://doi.org/10.1371/journal.ppat.1003362

[54] Mendez-Lagares, G., Lu, D., Merriam, D., Baker, C.A., Villinger, F., Van Rompay, K.K.A., et al. (2017) IL-21 Therapy Controls Immune Activation and Maintains Antiviral CD8(+) T Cell Responses in Acute Simian Immunodeficiency Virus Infection. AIDS Research and Human Retroviruses, 33, S81-S92. https://doi.org/10.1089/aid.2017.0160

[55] Williams, L.D., Bansal, A., Sabbaj, S., Heath, S.L., Song, W., Tang, J., et al. (2011) Interleukin-21-Producing HIV-1-Specific CD8 T Cells Are Preferentially Seen in Elite Controllers. Journal of Virology, 85, 2316-2324.

https://doi.org/10.1128/JVI.01476-10

[56] Borrow, P., Lewicki, H., Hahn, B.H., Shaw, G.M. and Oldstone, M.B. (1994) Virus-Specific CD8+ Cytotoxic T-Lymphocyte Activity Associated with Control of Viremia in Primary Human Immunodeficiency Virus Type 1 Infection. Journal of Virology, 68, 6103-6110.

[57] Ogg, G.S., Jin, X., Bonhoeffer, S., Dunbar, P.R., Nowak, M.A., Monard, S., et al. (1998) Quantitation of HIV-1-Specific Cytotoxic T Lymphocytes and Plasma Load of Viral RNA. Science, 279, 2103-2106. https://doi.org/10.1126/science.279.5359.2103

[58] Schmitz, J.E., Kuroda, M.J., Santra, S., Sasseville, V.G., Simon, M.A., Lifton, M.A., et al. (1999) Control of Viremia in Simian Immunodeficiency Virus Infection by CD8+ Lymphocytes. Science, 283, 857-860.

https://doi.org/10.1126/science.283.5403.857

[59] Jin, X., Bauer, D.E., Tuttleton, S.E., Lewin, S., Gettie, A., Blanchard, J., et al. (1999) Dramatic Rise in Plasma Viremia after CD8(+) T Cell Depletion in Simian Immunodeficiency Virus-Infected Macaques. The Journal of Experimental Medicine, 189, 991-998. https://doi.org/10.1084/jem.189.6.991 
[60] Kawada, M., Tsukamoto, T., Yamamoto, H., Takeda, A., Igarashi, H., Watkins, D.I., et al. (2007) Long-Term Control of Simian Immunodeficiency Virus Replication with Central Memory CD4+ T-Cell Preservation after Nonsterile Protection by a Cytotoxic T-Lymphocyte-Based Vaccine. Journal of Virology, 81, 5202-5211. https://doi.org/10.1128/JVI.02881-06

[61] Mckinnon, L.R., Kaul, R., Kimani, J., Nagelkerke, N.J., Wachihi, C., Fowke, K.R., et al. (2012) HIV-Specific CD8+ T-Cell Proliferation Is Prospectively Associated with Delayed Disease Progression. Immunology and Cell Biology, 90, 346-351.

https://doi.org/10.1038/icb.2011.44

[62] Shan, L., Deng, K., Shroff, N.S., Durand, C.M., Rabi, S.A., Yang, H.C., et al. (2012) Stimulation of HIV-1-Specific Cytolytic T Lymphocytes Facilitates Elimination of Latent Viral Reservoir after Virus Reactivation. Immunity, 36, 491-501.

https://doi.org/10.1016/j.immuni.2012.01.014

[63] Redel, L., Le Douce, V., Cherrier, T., Marban, C., Janossy, A., Aunis, D., et al. (2010) HIV-1 Regulation of Latency in the Monocyte-Macrophage Lineage and in CD4+ T Lymphocytes. Journal of Leukocyte Biology, 87, 575-588.

https://doi.org/10.1189/jlb.0409264 